\title{
IMPLEMENTASI PRINSIP 7P BAURAN PEMASARAN DALAM UPAYA MENINGKATKAN OMZET UKM PADA MASA PANDEMI COVID 19
}

\author{
Yulianto $^{1}$, Syamsul Mu`Arif ${ }^{2}$, Yenni Cahyani ${ }^{3}$, Suciati Muanifah ${ }^{4}$ \\ Universitas Pamulang \\ Email: dosen02238@unpam.ac.id
}

\begin{abstract}
The purpose of this Community Service activity is to carry out one of the Tri Dharma of Higher Education and its main objective is to provide solutions to problems faced by MSME business actors in the midst of the COVID-19 pandemic. In addition, it is hoped that with this community service the existence of higher education institutions can be make a major contribution to the development and application of science to society. The method used in this service is by sharing seasion in the form of webinars and also field assistance to find solutions to problems faced by MSME business actors. The results of this community service are in the form of making video advertisements to market AuRinS sambel balado products and the use of social media for product marketing. The knowledge gained from this Community Service is expected to be able to provide new enthusiasm for lecturers in an effort to develop themselves in providing direction, delivery of material and motivation as well as contributing to the development of the business world, especially the MSME sector both around the campus and nationally.
\end{abstract}

Keywords: 7P Marketing mix, MSMEs, Covid-19 Pandemic

\begin{abstract}
Abstrak
Tujuan dari kegiatan Pengabdian Kepada Masyarakat ini adalah untuk melaksanakan salah satu Tri Dharma Perguruan Tinggi dan tujuan utamanya adalah untuk memberikan solusi atas permasalahan yang dihadapi oleh para pelaku usaha UMKM di tengah pandemi covid 19. Selain itu diharapkan dengan pengabdian kepada masyarakat ini keberadaan perguruan tinggi dapat memberikan kontribusi besar kepada pengembangan dan penerapan keilmuan kepada masyarakat. Metode yang digunakan dalam pengabdian ini yaitu dengan cara sharing seasion dalam bentuk webinar dan juga pendampingan lapangan guna mendapatkan jalan keluar atas permasalahan yang dihadapi pelaku usaha UMKM. Hasil pengabdian kepada masyarakat ini berupa pembuatan video iklan untuk memasarkan produk AuRinS sambel balado serta pemanfaatan sosial media untuk pemasaran produk. Ilmu yang didapatkan pada Pengabdian Kepada Masyarakat kali ini diharapkan mampu memberikan semangat baru bagi dosen dalam upaya mengembangkan diri memberikan pengarahan, penyampaian materi dan motivasi serta berkontribusi bagi perkembangan dunia usaha khususnya sektor UMKM baik di sekitar lingkungan kampus maupun secara nasional.
\end{abstract}

Kata Kunci: 7P Bauran pemasaran, UMKM, Pandemi Covid-19 


\section{A. PENDAHULUAN}

Pembangunan perekonomian nasional merupakan bagian dari tujuan utama dari adanya pembanguna yang terus dilakukan oleh pemerintah Indonesia, yang pada akhirnya tujuan pembangunan tersebut guna mencapai masyarakat yang adil dan makmur. Hal tersebut akan berhasil dicapai apabila setiap pilar ekonomi yang ada di negara ini berperan aktif didalam proses pembangunan.

Salah satu pilar utama yang mendorong perekonomian Indonesia adalah Usaha Mikro Kecil dan Menengah (UMKM), berdasarkan pada data Kemenkop dan UKM Republik Indonesia pada tahun 2017 mencatat bahwa UMKM mempunyai pangsa pasar sebesar $99,99 \%$ atau 62,9 juta unit dari total keseluruhan pelaku usaha yang ada di Indonesia, sementara itu usaha besar hanya memiliki pangsa pasar sebesar 0,01\% atau sekitar 5.400 unit. Usaha mikro menyerap tenaga kerja sekitar 107,2 juta atau sebesar $89,2 \%$, sementara usaha kecil sebesar 5,7 juta (4,74\%) dan usaha menengah sebanyak 3,73 juta $(3,11 \%)$, sementara usaha besar hanya menyerap tenaga kerja sekitar 3,58 juta jiwa. Dapat dikatakan bahwa secara total UMKM mampu menyerap tenaga kerja sekitar 97\% dari keseluruhan tenaga kerja nasional, dan usaha besar hanya menyerap sekitar 3\% dari total tenaga kerja nasional.

Agar setiap jenis usaha yang tergolong dalam UMKM dapat bertahan dan meningkat kinerjanya dari masa ke masa, maka diperlukan adanya update informasi terkait dengan halhal yang berhubungan dengan konsep pemasaran, kewirausahaan, perkoperasian, manajemen dan hal lainnya. Jika dilihat pelaku usaha UMKM memiliki beberapa keunggulan diantaranya adalah mampu menyerap tenaga kerja tidak terdidik dan tidak terlatih dalam jumlah besar, kebanyakan UMKM menghasilkan produk baik barang atau jasa dengan elastisitas permintaan tehadap pendapatan yang masih rendah. UMKM juga sangat membantu dalam membuka lapangan kerja khususnya bagi masyarakat Indonesia yang memiliki pendidikan rendah.

Hidup segan mati tak mau, setidaknya itulah yang bisa diibaratkan kepada kondisi pelaku UMKM di tengah pandemi Covid-19 saat ini. Penularan virus corona yang demikian cepat dan masif telah memaksa pemerintah menerapkan Pembatasan Sosial Berskala Besar (PSBB), yang juga berdampak mematikan berbagai aktivitas bisnis pelaku UMKM. Pemerintah menyadari bahwa kebijakan PSBB memiliki dampak yang begitu besar terhadap perekonomian. Namun, pemerintah harus memutuskan pilihan, antara kepentingan ekonomi atau keselamatan warga negara. Sudah pasti dengan penuh perhitungan dan konsekuensi risikonya, keselamatan warga negara adalah di atas segala-galanya. Kebijakan PSBB tidak hanya membatasi aktivitas usaha para pelaku UMKM, tetapi juga hampir semua bidang usaha, baik skala besar, bahkan pekerja nonformal terdampak dengan kebijakan ini. Sektor usaha skala menengah dan besar di bidang pariwisata beserta turunannya seperti hotel, restoran, kafe, travel, pusat hiburan dan transportasi sejak sekitar dua bulan lalu sudah mengalami tekanan usaha yang sangat berat.

Berkaca pada krisis moneter 1998 dan krisis keuangan global 2008, tatkala perusahaanperusahaan skala besar banyak yang tumbang, sebaliknya sektor UMKM tampil sebagai penyelamat dan penopang perekonomian nasional. Ketangguhan UMKM menjadi modal utama, membawa perekonomian nasional selamat dari krisis dan perlahan tapi pasti perekonomian kita dapat pulih kembali. UMKM saat itu mampu menggerakkan ekonomi akar rumput dan menjaga daya beli masyarakat. Namun, kini kondisinya jauh beberda kala pandemi Covid-19 melanda negara kita. UMKM tidak lagi tangguh, lumpuh, tidak dapat lagi diandalkan sebagai penopang perekonomian bangsa. Pangsa pasar yang dimilikinya, berupa kebutuhan masyarakat sehari-hari, baik sandang maupun pangan, menyempit. 
Berdasarkan pada hasil survai dan pantauan pendahuluan tentang keberadaan UMKM di Tangerang Selatan, maka tim PKM bekerja sama dengan RPM Institute melakukan kerja sama untuk mengadakan Pengabdian Masyarakat dosen-dosen Universitas Pamulang dalam bentuk pendampingan usaha UMKM pada usaha-usaha yang berada di bawah koordinasi RPM Institute. Adapun data pelaku UMKM yang bersedia dilakukan pendampingan dapat dilihat pada tabel berikut.

Tabel 1

Peserta UMKM Berdasarkan Kebutuhan

\begin{tabular}{|c|c|c|c|}
\hline No & PESERTA UMKM & MEREK USAHA & KEBUTUHAN UTAMA \\
\hline 1 & Sekar Ariwati & Sekar Ku & Dibantu membuat Laporan Keuangan \\
\hline 2 & Hesti Widyo Asih & Heiko Food/HeiChoko & Dibantu membuat Laporan Keuangan \\
\hline 3 & Siti Nurfadilah & Tamma food & Saluran Distribusi Penjualan \\
\hline 4 & Yafiet & Nasi kebuli instan & Strategi Pemasaran \\
\hline 5 & Euis Chodijah & Sahabat Ibu/ LeBON & Marketplace \\
\hline 6 & Henny & Pempek & Marketplace \\
\hline 7 & Restia Widhiyanti & Umifa Culinary & Dibantu membuat Laporan Keuangan \\
\hline 8 & Rini Sonatha oktafia & AuRinS sambel balado & Strategi Pemasaran \\
\hline 9 & Heni Purnamawati & Teras Pringgondani & Saluran Distribusi Penjualan \\
\hline 10 & Asep Abdul R & Al Asna Madu Hutan Sumatera & Saluran Distribusi Penjualan \\
\hline 11 & riyati & salon khusus wanita dan anak-anak & Dibantu membuat Laporan Keuangan \\
\hline 12 & Indra utama & Bandar kurma & Strategi Pemasaran \\
\hline 13 & Putri Diana & Omah Peyek & Dibantu menghitung HPP dan Harga Jual \\
\hline 14 & Uni Purnamasari & Warung jajanan dan reseller online & Strategi Pemasaran \\
\hline 15 & Siti aisyah & Es cendol khas bandung kiki & Strategi Pemasaran \\
\hline 16 & Siti Aminah & Soto Mie Bogor & Strategi Pemasaran \\
\hline 17 & Ibu Susanti & Serba bakso & Marketplace \\
\hline 18 & Ega Kartini & Pontir Jaya Food & Saluran Distribusi Penjualan \\
\hline 19 & Sitirofiah & Warung Ruby & Strategi Pemasaran \\
\hline 20 & Budi & Halia Jahe Merah & Saluran Distribusi Penjualan \\
\hline 21 & Nurhayati & Makhay_reseppisan & Marketplace \\
\hline 22 & Mei indriani & Kuliner/jaunic food & Dibantu membuat Laporan Keuangan \\
\hline 23 & Nunu Setyaningsih & Nudi Solusi Nusantara/ NUDI & Strategi Pemasaran \\
\hline 24 & Nurlaela & Makanan & lainnya \\
\hline 25 & yulia & jajanan murah & Manajemen usaha \\
\hline
\end{tabular}

Secara umum kebutuhan yang diperlukan oleh para pelaku usaha UMKM terbagi kedalam 5 (lima) kategori, yaitu: Laporan Keuangan, Strategi Pemasaran, Strategi Distribusi Penjualan, Marketplace, Perhitungan HPP dan penentuan harga jual, Manajemen Usaha dan Lain-lain.

Adapun yang menjadi binaan kami adalah UMKM yang bergerak dalam bidang produksi dengan merek dagang "AuRinS sambel balado" dengan Ibu Rini Sonatha Oktafia 
selaku pemilik usaha, permasalahan yang kami temukan dalam UMKM binaan kami AuRinS sambel balado, yaitu:

1. Belum adanya saluran pemasaran yang baik,

2. Penjualan masih mengandalkan reseller,

3. Adanya beberapa reseller yang telah memiliki pelanggan tetap akhirnya berhenti membeli produk dari Aurin Sambal Balado dan membuat produk sendiri akan tetapi mengatasnamakan produk Ibu Rini selaku pemilik dari Aurin Sambal Balado sehingga hal ini merugikan citra usaha Ibu Rini dari segi rasa,

4. Belum melakukan penjualan secara daring dengan memanfaatkan marketplace,

5. Promosi masih dilakukan hanya dengan mengandalkan status dari aplikasi pesan whatapps.

Profil UMKM di Indonesia terdiri atas tiga kluster besar, diantaranya kluster produsen, usaha dagang, dan jasa. Pada klaster produsen umumnya menghasilkan bermacam makanan dan minuman seperti tahu, tempe, kue basah, bakso, mie, sirop, sambal dan lainnya. Termasuk aneka sandang seperti pakaia atau batik, tas, sepatu, kerajinan dalam bentuk souvenir, mebel, percetakan dan industri kreatif. Klaster usaha dagang mencakup pedagang kaki lima, restoran, kafe, catering, aneka warung, kuliner, toko pakaian atau fashion, toko sembako, dan lainnya. Sedangkan klaster usaha jasa seperti transportasi online, travel wisata dan umroh, kontraktor, pengadaan barang atau jasa, bengkel, logistik, salon, klinik, barbershop, event organizer, desain dan percetakan, dan lainnya. Pangsa pasar dari kesemua bidang usaha UMKM tersebut akan sangat ditentukan oleh pergerakan manusia sebagai konsumen atau pelanggan. Semakin lama kebijakan bekerja dari rumah (work from home) dan PSBB, maka nasib usaha UMKM semakin tidak pasti, bahkan yang masih bertahan perlahan akan menyusul menutup usahanya.

Walaupun selama ini pelaku UMKM masih kurang mendapat perhatian dari pemerintah dari sisi pembinaan, pemberdayaan dan pengembangan, namun realitasnya peran UMKM dalam menopang perekonomian nasional tidaklah bisa dipandang sebela mata. Sampai saat ini belum ada yang memastikan kapan pandemic Covid-19 ini akan berakhir. Namun, jika penerapan PSBB ini masih berkepanjangan, aktivitas usaha UMKM akan mati suri, dampaknya angka kemiskinan dan pengangguran akan semakin tinggi, yang tentu akan menjadi beban sosial yang harus dipecahkan oleh pemerintah. Dampak Covid-19 ini memang teramat sulit bagi UMKM, bahkan bisa digolongkan sebagai kejadian luar biasa yang sulit diprediksi sebelumnya. Sangatlah ironis kondisi yang dialami UMKM saat ini, yang harus menanggung ketirnya usaha akibat Covid-19.

\section{B. METODE PELAKSANAAN}

Pelaksanaan pengabdian dilakukan dengan tiga tahapan, dimana tahapan pertama merupakan tahapan persiapan. Pada tahapan ini kelompok pengabdian melakukan survai pendahuluan untuk mengetahui kondisi pelaku usaha UMKM di lapangan mengenai masalah apa yang perlu mendapatkan pendampingan untuk ditemukan jalan keluarnnya. Tahap selanjutnya adalah tahap pelaksanaan pengabdian kepada masyarakat. Dalam tahapan ini tim Pengabdian melakukan sosialisasi dan pendampingan usaha kepada para pelaku UMKM guna mendapatkan solusi yang diperlukan dalam proses pengembangan usaha, khususnya pada masa pendemi covid 19 ini. Tahap yang terakhir yaitu dilakukan evaluasi atas hasil yang didapatkan selama proses pendampingan usaha, apakah masalah teratasi atau belum. Indikator keberhasilan dari pengabdian masyarakat ini adalah berhasil memberikan invovasi baru, cara, metode didalam usaha guna memecahkan permasalahan yang didapatkan selama survai pendahuluan. 
Kegiatan ini secara eksplisit berupa adanya pertemuan dan komunikasi yang intensif diantara tim PKM dengan koordinator pengabdian masyarakt secara bersama-sama melaksanakan analisa situasi, identifikasi kebutuhan, membuat perencanaan, melaksanakan program, melaksanakan evaluasi program. Kesepakatan-kesepakatan yang telah dibuat oleh tim pelaksana dari dosen-dosen UNPAM dengan koordinator UMKM, tentang materi pelatihan dan monitoring langsung secara berkala dari tim pelaksana PKM. Secara operasional metode pelaksanaan program PKM untuk yang digunakan dalam rangka memecahkan masalah yang dihadapi UMKM di atas, yakni melalui tahapan sebagai berikut:

1. Analisis situasi dan identifikasi kebutuhan UMKM,

2. Perencanaan program dengan mempertimbangkan aspek sarana, prasarana, dosen, pelaku UMKM. Persiapan tersebut diantaranya materi yang disiapkan adalah : Implementasi Prinsip 7P Bauran Pemasaran Dalam Upaya Meningkatkan Omzet UKM pada Masa Pandemi Covid 19,

3. Evaluasi program dilakukan untuk mengetahui sejauh mana ketercapaian pelaksanaan kegiatan pendampingan dan pelatihan. Evaluasi kegiatan dilakukan selama proses kegiatan berlangsung, yaitu pada saat peserta kegiatan mengikuti pendampingan. Selain itu, melakukan wawancara yaitu memberikan pertanyaan yang terkait dengan pelaksanaan pendampingan secara individu. Hal ini dilakukan untuk mengetahui bagaimana tanggapan peserta tentang pelaksanaan kegiatan pendampingan dan pelatihan strategi pemasaran. Dengan adanya evaluasi ini, tim pelaksana kegiatan pendampingan dan pelatihan dapat meyimpulkan bahwa kegiatan pendampingan dan pelatihan dapat menambah dan meningkatkan pengetahuan para pelaku UMKM.

\section{HASIL DAN PEMBAHASAN}

\section{Tahap Persiapan}

Sebelum melakukan pengabdian kami para dosen UNPAM melakukan survai pendahuluan ke RPM Institute Tangerang Selatan. Pendampingan ini dilakukan dengan tujuan untuk memecahkan permasalahan yang ada pada UMKM scaleup RPM Institute. Selanjutnya team PKM yang terdiri dari empat orang dosen melakukan Forum Group Discussion (FGD) untuk mempersiapkan pelaksanaan Pengabdian Kepada Masyarakat (PKM) untuk sharing seasion pada 30 Oktober 2020 dilanjut dengan pendampingan UMKM dilapangan.

\section{Tahap Pelaksanaan Pengabdian Kepada Masyarakat}

Setelah dilakukan sharing seasion pada 30 Oktober 2020 berlanjut pada pendampingan UKM AuRinS sambel balado yang merupakan salah satu UKM binaan RPM Institute, pendampingan dilakukan pada tanggal 31 Oktober 2020 sampai 28 November 2020 dengan berbagai media baik Zoom maupun Whatsapp. Kegiatan ini terlaksana atas kerjasama antara Universitas Pamulang dengan RPM Institute. Kegiatan PKM ini mengambil judul "Implementasi Prinsip 7P Bauran Pemasaran Dalam Upaya Meningkatkan Omzet UKM pada Masa Pandemi Covid 19"

\section{Tahap Pendampingan}

Untuk melaksanakan kegiatan PKM ini digunakan beberapa metode pendampingan yaitu sebagai berikut :

a. Webinar sebagai pembuka dengan Tema "Sharing Sukses Bisnis Di Tengah Pandemi"

b. Diskusi Dan Tanya Jawab, Setelah pembicara selesai membawakan materinya, dilanjutkan dengan sesi diskusi dengan tanya jawab dilanjutkan dengan pemilihan UKM untuk dilakukan pendampingan. 
c. Sharing seasion dengan UKM yang didampingi untuk menentukan masalah utama yang dihadapi oleh pelaku UKM khususnya di masa pendemi ini.

d. Pendampingan lapangan, melakukan pendampingan secara lebih intensif kepada pelaku UKM yang didampingi dengan jalan memberikan wacana dalam bentuk ceramah dengan materi yang telah disesuaikan dengan permasalahan mitra, presentasi dibawakan dengan judul "Implementasi Prinsip 7P Bauran Pemasaran Dalam Upaya Meningkatkan Omzet UKM pada Masa Pandemi Covid 19" untuk menjawab permasalahan mitra terkait dengan Strategi Pemasaran dan sharing terkait dengan cara-cara membuat paten untuk produk yang dihasilkan.

e. Pendampingan pembuatan toko di marketplace dan pembuatan video pemasaran, video pemasaran dibuat berdasarkan pada permasalaahan mitra yang mana masih merasakan kesulitan didalam memasarkan produknya, pendampingan pembuatan video pemasaran ini diharapkan mampu menjadi salah satu jalan untuk mengiklankan produknya di berbagai sosial media.

\section{KESIMPULAN DAN SARAN}

\section{Kesimpulan}

Pelaksanaan kegiatan Pengabdian Kepada Masyarakat dalam bentuk pendampingan usaha UKM berjalan dengan lancar dan mendapat sambutan positif baik dari RPM Institute maupun dari Ibu Rini selaku pemilik UKM dengan merek dagang AuRinS sambel balado. Harapan kami selaku dosen dengan adanya kegiatan PKM ini dapat memberikan solusi atas permasalahan yang dihadapi oleh usaha UMKM khususnya pada masa pendemi ini.

Dalam penyusuna laporan PKM ini jauh dari sempurna oleh karena itu saran dan kritik yang sifatnya membangun kami harapkan. Semoga kegiatan PKM ini dapat bermanfaat bagi masyarakat di sekitar Universitas Pamulang dan lebih luas lagi. Dengan adanya kegiatan ini diharapkan dapat menyelesaikan permasalahan yang dihadapi oleh sektor usaha UMKM khususnya UMKM AuRinS sambel balado.

Akhir kata, kami selaku dosen pengabdi pada kegiatan ini banyak mengucapkan terima kasih kepada semua pihak yang mendukung kegiatan ini dan memohon maaf bila ada kekurangan dan kesalahan didalam pelaksanaan pendampingan.

\section{Saran}

Berdasarkan hasil pendampingan kegiatan PKM yang sudah dilakukan, maka kami dari team Dosen Universitas Pamulang memberikan saran yaitu sebagai berikut :

1. Untuk RPM Institute kedepan diharapkan untuk bisa bekerjasama berkelanjutan dalam rangka untuk mendukung perkembangan sektor usaha UMKM guna menunjang kesejahteraan besama yang pada akhirnya akan membawa dampak pada pemulihan ekonomi secara nasional.

2. Untuk UKM AuRinS sambel balado kedepan agar lebih memaksimalkan pemanfaatan sosial media untuk menambah luas jangkauan pemasaran, karena sama-sama kita ketahui bahwa perkembangan teknologi harusnya lebih memudahkan setiap kegiatan manusia, dalam hal ini untuk pemanfaatan akses pemasaran produk.

\section{DAFTAR PUSTAKA}

Dumilah, R., Sunarto, A., Solihin, D., \& Maulida, H. (2020). Pelatihan Pemanfaatan Media Sosial Untuk Promosi Usaha Atau Bisnis Bagi Siswa. DEDIKASI PKM, 1(1), 26-33.

https://www.jurnal.id/id/blog. UMKM, Tantangan Pasar dan Solusi Digital. (diakses pada 9 November 2020) 
https://www.liputan6.com. Beda Kondisi UMKM Saat Pandemi Corona di 2020 dengan Krisis Ekonomi 1998. (diakses pada 9 November 2020)

Ida Farida et al. (2016)"Analisa Pengaruh Bauran Pemasaran 7P Terhadap Kepuasan Pelanggan Pengguna Gojek Online". Jurnal Riset Manajemen dan Bisnis Vol. 1, No. 1, hal 31-40

Muslikh, Suhirman. (2019) "Program Pendampingan Bagi Pelaku UMKM Menuju Usaha Yang Berdaya Saing dan Berbasis Teknologi Informasi di Cempaka Putih Jakarta Pusat". Jurnal PKM Universitas YARSI Jakarta.

Qurbani, D., Mardiana, S., \& Nugroho, R. D. (2020). Meningkatkan Minat Dan Potensi Generasi Milenial Khususnya Siswa-Siswi SMK Darussalam Untuk Memulai Bisnis Online Dengan Sistem Dropship. DEDIKASI PKM. 1 (3).

Solihin, D., Susanto, N., Setiawan, R., Ahyani, \& Darmadi. (2020). PENERAPAN STRATEGI PEMASARAN SEBAGAI UPAYA MENINGKATKAN USAHA KECIL DAN MENENGAH WARGA DI KELURAHAN PANINGGILAN UTARA CILEDUG. ABDI LAKSANA, 1(3), 351-355.

Solihin, D. (2020). Faktor-Faktor Yang Mempengaruhi Kinerja Pemasaran Pada PT Prima Ufuk Semesta (Studi Empiris Pada Outlet Rekanan PT. Prima Ufuk Semesta di Wilayah JABODETABEK). Jurnal Semarak 3 (1), 20-26.

rumahpemberdayaan.com (diakses pada 9 November 2020)

Undang-Undang No. 20 Tahun 2008 tentang Usaha Mikro, Kecil dan Menengah 